UNITED STATES DEPARTMENT OF THE INTERIOR

GEOLOGICAL SURVEY

RIPPLES AND SAND WAVES IN NORTON BASIN:

BED-FORM ACTIVITY AND SCOUR POTENTIAL

By

C. Hans Nelson, Michael E. Field, David A. Cacchione,

David E. Drake, and Tor H. Nilsen

Open-File Report

$80-659$

This report is preliminary and has not been reviewed for conformity with U. S. Geological Survey editorial standards and stratigraphic nomenclature. Any use of trade names is for descriptive purposes only and does not imply endorsement by the U. S. Geological Survey. 


\section{Ripples and Sand Waves in Norton Basin; Bed-form Activity, and Scour Potential}

C. Hans Nelson, Michael E. Field, David A. Cacchione, David E. Drake, and Tor H. Nilsen

\section{INTRODUCTION}

Strong currents are present throughout much of the northern Bering Sea, particularly where westward land projections interject into the prevailing northward flow, such as in the eastern Bering Strait area (see fig 1, Nelson, Holocene transgression article this volume) (Fleming and Heggarty, 1966). In such regions large bedforms develop and migrate to form an unstable sea floor that can be a potential hazard to platform foundations and pipelines. Such potentially hazardous areas must be identified, their history assessed, and magnitude of future problems predicted. This paper outlines regions of mobile bedforms (fig. I) and presently known aspects of their activity.

\section{Identification and Distribution of Bedform and Scour Features}

Large bedforms and scour features have been recognized and mapped with side-scan sonar profiles and basic internal structure sometimes has been determined by high-resoltuion profiles (fig. 2 ). Detailed surficial observations have been made with underwater television and bottom photos, and subsurface stratigraphic history has been determined by analyses of vibracores and box cores (figs. 3 and 4 ).

In general, only small-scale bedforms and large-scale scour features are found in Norton Sound (fig. 1) (Larsen et al., 1979). In contrast, Chirikov Basin is characterized by coarser grain size than Norton sound (see fig. $\epsilon$, Nelson, Holocene trangression article this volume) (Nelson and Hopkins, 1972; McManus et al., 1974 and 1977.), and numerous fields of mobile bedforms (fig. 1). In the vicinity of sledge Island, most of the sea floor has been stripped bare of sediment (Nelson and Hopkins, 1972), suggesting intense current scour (fig. 1). Just east and west of the scoured region and extending across the nearshore area of the Nome coastal plain, extensive sand wave and rippie fields are found (fig. 1) (Hunter and Thor, this volume).

From Pt. Spencer spit west to King Island a series of sarib ridges and swales exist (fig. 2). The crest of each shoal is covered with sand waves of varying types and sizes (fig. 5). To the north of the ricge and swale area toward Bering strait, extensive sand-ribbon fields are found with occasional sand dune areas (fig. 1); however, the area is not completely surveyed. The sand ribbon fields indicate a sediment-starved region and possibly one prone to current scour, since the current speeds intensify toward Bering strait (see fig. 1, Nelson Holocene transgression article this volume). Further north within Bering Strait itself, gravel and shell pavements are noted (Nelson and Hopkins, 1972) in addition to sporadic occurrences of extremely large sand waves (Grim and McManus, 1970).

off the eastern and western ends of St. Lawrence Island, major sand ridge and swale topography is known (Hopkins et al., 1976), and ripple fields are common to the northwest off St. Lawrence Island (fig. 1). 
Character and Origin of Mobile Bedform Features

In the ridge and swale area between King Island and the mainland, swale areas appear to undergo erosion periodically. Generally, a thin veneer of fine, modern mad at the surface overlies Pleistocene peaty mads (fig. 6 ). Fine mud, signifying sluggish currents, is typically deposited rapidly in depressions (fig. 7). The lack of thick deposits, and very old radiocarbon dates close to the surface, however, suggest that muds have periodically been swept away so that there has been no net mud accumulation for thousands of years. In fact, a radiocarbon date on peat $20 \mathrm{~cm}$ below the surface of the swale between Tin City and York Shoal is $>30,000 \mathrm{BP}$, indicating that significant quantities of younger sediment have been stripped away, possibly by currents (fig. 6 ).

In contrast to swales, sand ridges are definitely constructive as is shown in the sparker seismic profiles (figs. 8 and 9 ). The morphology of the more landward shoals mirrors the shape of the modern Pt. Spencer spit and these shoals may be ancient analogues (fig. 3). Indeed, depths of shoal crests coincide with proposed still-stand depths of ancient submerged strandines noted elsewhere in northern Bering Sea (Nelson and Hopkins, 1972). Sand ridges behind large obstructions to the northward current flow, such as King Island and Cape Prince of Wales (see area north of station 88 in fig. 3), may be lee-side accumulations of sediment unrelated to past paralic environments.

Although formation of the basic ridge structures $(15-30 \mathrm{~km}$ long, see cross-hatched areas in fig. 3) may relate to past transgressive history, these structures also have a modern history of modification by development of sand waves and ripple fields. Sand waves are 1 to $2 \mathrm{~m}$ high and have crest spacings ot either 10 to $20 \mathrm{~m}$ or 150 to $200 \mathrm{~m}$ (figs. 9 and 10E). Superimposed on the sand waves are smaller-scale current-asymmetric (figs. $10 B$ and $C$ ) and wave oscillation (fig. 10A) ripples with heights of approximately 4 to $10 \mathrm{~cm}$ and wavelengths of approximately 20 to $100+\mathrm{cm}$. Except for the oscillation ripples, bedforms of all sizes are asymmetric to the north and their asymmetry coincides with the prevailing northward flowing currents (see fig. 1, Nelson, Holocene trangression article this volume) (Coachman et al., 1976).

Growth and movement of the sand wave fields on shoal crests is definitely intermittent, just like the apparent erosional history of the swales. Ice gouges observed to cut sand wave fields on inner shoals in the summer of 1976 proved that no major change in the sand-wave fields had occurred since the previous winter, or possibly for mmany years before, depending on how recently the gouge occurred. During the fall 1976 field season, only low speed oscillatory bottom currents up to $15 \mathrm{~cm} / \mathrm{sec}$ (fig. 11) were measured. Underwater television observation showed only the development of oscillation ripples (fig. 10A) and sonographs showed only decayed, inactive sand waves (figs. 10D and $\mathrm{E}$ ). Thus, sand waves were not active then or apparently for some time before. A piece of wood found at $30 \mathrm{~cm}$ depth in a sand wave, however, had an age of 1155 BP (Teledyne Isotopes \#I-9773). This date proved that bedforms with heights of at least this order of magnitude $(30 \mathrm{~cm})$ had been actively migrating since sea level reached its present height, and that sand waves are not, therefore, relict features from some past time of lowered sea level. 
Data collected in the field season of 1977 indicates that there had been significant bed-form activity since the 1976 survey. In some areas with replicate side-scan lines, large-scale sand waves reformed from decayed fields and developed subsets of superimposed smaller-scale sand waves offset at an angle (fig. 10E); however, sand waves on some other ridges remained unmodified from 1976 to 1977 (fig. 10D). Underwater television videotapes show that small-scale ripple fields were undergoing active modification at the time of observation in 1977. Instead of the oscillation ripples observed during the storm conditions in 1976, there were actively migrating asymetric straightcrested ripples in the troughs (fig. 10C) and linguoid ripples on the upcurrent face of sand waves (fig. 10B). Northward-flowing bottom currents measured with the shipboard profiling current meter ranged from $20-40 \mathrm{~cm} / \mathrm{sec}$, with a near-bottom average current speed of $24 \mathrm{~cm} / \mathrm{sec}$ (fig. 12).

Observations of a series of ice gouges also confirm that there has been recent, active migration of sand waves near Port clarence (fig. 13). Ice gouges range from fresh to highly modified by sand wave migration (fig. 12F); thus, extensive movement within some sand-wave fields has occurred recently. Lack of modification of gouges (fig. 13) and continued presence of decayed bedforms in some locations indicates that current activity in the Port clarence area varies both in time and space. Only long-term current measurements from from several locations will resolve this complex current regime and allow predictability of mobile-bedform activity.

\section{Conclusions and Needs for Further Study}

Surveys in September 1976, during a period of subsiding storm waves from the north, showed only oscillatory movement of sand on ripple crests. A maximum speed of the north-flowing coastal current of about $15 \mathrm{~cm} / \mathrm{sec}$ was measured near the bottom and no net-bedload movement was observed. Freshlooking ice gouges cutting inshore ripples indicated that bedload movement had been negligible in this zone since ice break-up in the spring. The second survey, in July 1977, was made during very calm weather, yet significant bedload movement was observed on ridge crests at water depths of 10 to $30 \mathrm{~m}$. Northward flowing bottom currents measured up to $40 \mathrm{~cm} / \mathrm{sec}$. Linguoid ripples and straight-crested ripples were observed moving on the stoss slopes and troughs of sand waves, respectively. Ice gouges in varying states of preservation indicated active bedload transport on deeper ridge crests.

Sand-wave movement and thus bedload transport apparently occurs during calm weather, and maximum sediment transport apparently occurs when major southwesterly storms generate sea level set-up in the eastern Bering Sea that enhances northerly currents (Cacchione and Drake, 1979; Schumaker and Trip, 1979). Strong north winds from the Arctic, however, reduce the strength of the continuous northerly currents and thereby reduce the amount of bedload transport.

Studies to date indicate that the greatest potential for scour around obstructions exists in regions of sand ribbons and gravel-plus-shell pavements which occur within straits areas (fig. 1). The Port Clarence sand wave area has the most rapidly changing relief and the scour in sand wave crests may reach depths of up to $2 \mathrm{~m}$ (fig. 9). Data from replicate lines in 1976 and 1977 show that such scour may occur in some areas of the Port clarence sand wave field each year (fig. 10). 


\section{ACKNOWLEDGMENTS}

Devin Thor, Mathew Larsen, Terry Hallinan, William Richmond, Jeff Patry and James Evans compiled data and prepared figures. We thank the officers, crew, and shipboard scientific staff for their concerted effort in the detailed study of sand wave areas.

The cruises were supported jointly by the U.S. Geological Survey and by the Bureau of Land Management through interagency agreement with the National Oceanic and Atmospheric Administration, under which a multiyear program responding to needs of petroleum development of the Alaska continental shelf is managed by the outer Continental Shelf Environmental Assessment Program (OCSEAP) Office.

\section{REFERENCES CITED}

Cacchione, D.A., and Drake, D.E., 1979) sediment transport in Norton Sound, Alaska: Regional patterns and GEOPROBE system measurements: U.S. Geological Survey Open-File Report 79-1555.

Coachman, L.K., Aagaard, Knut, and Tripp, R.B., 1976, Bering Strait: The regional physical oceanography; Univ. of Washington Press, 186 p.

Fleming, R.H., and Heggarty, D., 1966, Oceanography of the southeastern Chukchi Sea, in Wilimovsky, N.J., Wolfe, J.M., (eds.), Environment of Cape Thompson Region, Alaska: U.S. Atomic Energy Commission, p. 697-754.

Grim, M.S., and McManus, D.A., 1970, A shallow seismic profiling survey of the northern Bering Sea: Marine Geology, v. 8, p. 293-320.

Hopkins, D.M., Nelson, Hans, Perry, R.B., and Alpha, Tau Rho, 1976 Physiographic subdivisions of the Chirikov Basin, northern Bering Sea; U.S. Geol. Survey Prof. Paper 759-B, p. B1-B7.

Larsen, M.C., Nelson, C.H., and Thor, D.R., 1979, Geologic implications and potential hazards of scour depressions on Bering shelf, Alaska: Environmental Geology, v. 3, p. 39-47.

McManus, D.A., Venktaratham, K., Hopkins, D.M., and Nelson, C.H., 1974, Yukon River sediment on the northernmost Bering Sea shelf: Jour. Sed. Pet., v. 44, no. 4, p. 1052-1060.

McManus, D.A., Venkataratham, Kolla, Hopkins, D.M., and Nelson, Hans, 1977, Distribution of bottom sediments on the continental shelf, northern Bering Sea: U.S. Geol. Survey, Prof. Paper 759-C, p. C1-C31.

Nelson, C.H., and Hopkins. D.M., 1972, Sedimentary processes and distribution of particulate gold in the northern Bering Sea: U. S. Geol. Survey Prof. Paper 689, 27 p.

Nelson, C. H., and Creager, J.S., 1977, Displacement of Yukon-derived sediment from Bering Sea to Chukchi sea during Holocene time: Geology, v. 5, pp. 141-146.

Schumacher, J.D., and Tripp, R.B., 1979, Response of northeast Bering Sea shelf waters to storms: EOS, 60,856 . 
Figure 1. Index map of Northern Bering Sea showing major areas of mobile bedforms.

Figure 2. Detailed high-resolution seismic.profile and side-scan tracklines collected in 1976 and 1977 in northeastern Chirikov Basin. Miniranger precision navigation was ${ }^{*}$ used to replicate tracklines. Bathymetric contours are in meters: hachured areas outline major sand ridges that exhibit sand-wave fields.

Figure 3. Detailed transects of underwater television and bottom camera stations taken in northeastern Chirikov Basin. Bathymetric contours are in meters: ' hachured areas outline major sand ridges that exhibit sand-wave fields.

Figure 4. Location of detailed sampling stations in area of sand ridges west of Port Clarence, Alaska.

Figure 5. Location of active bedforms in northeastern Chirikov Basin. Bathymetric contours are in meters; hachured areas outline major sand ridges that exhibit sand-wave fields.

Figure 6. Stratigraphy of nearsurface sediment observed in box and vibracores from sampling transects across sand ridges near Port Clarence. Location of transects is shown in figure 2 .

Figure 7. Grain-size distribution in sand ridge area west of Port Clarence.

Figure 8. Line drawings of high-resolution seismic profiles across major sand ridges shown in figure 2. Note that the "sand ridges" are constructional features overlying parallel of folded, older sediment. Names of ridges are given in figure 3.

Figure 9. $3.5 \mathrm{kHz}$ seismic profiles with associated sonographs taken over sand ridges covered by large and smallscale, active sand waves. Records are from the York Shoal area shown in figure 3.

Figure 10. Bedforms and ice gouges observed on sand ridges west of Port Clarence. A-Videotape photo of oscillation ripples taken on the crest of Lost River Shoal in September, 1976 (ripple height approximately $4 \mathrm{~cm}$ and wave length about $20 \mathrm{~cm}$; water depth $12 \mathrm{~m}$ ). B-Bottom camera photo of asymmetric linguoid ripples on the stoss face of a sand wave on York Shoal taken in July, 1977 (ripple height approximately 2-3 cm and wave length about $10 \mathrm{~cm}$; water depth $20 \mathrm{~m}$ ). C-Bottom camera photo taken at same location as B showing asymetric straight-crested ripples of the same scale, but located in a trough between sand waves of $0.5 \mathrm{~m}$ wave height, approximately. D-Sonographs of unchanged sand waves on the crest of TIn City Shoal. E-Sonographs of sand waves on York Shoal that changed from decayed bedforms in 1976 to two active sets of bedforms in 1977 (large-scale waves $2 \mathrm{~m}$ high and 150-200 m wave length; small-scale waves $0.5 \mathrm{~m}$ high and 10-20 $\mathrm{m}$ wave length). F-Series of sonographs showing different stages of ice gouge modification by actively migrating sand-wave fields. 
Figure 11. Summary of profiling currert meter data collected at stations in the sand-wave fields west of Port Clarence in september, 1976. . Hachured areas depict major sand ridges with sand-wave fields; contour interval is $4 \mathrm{~m}$.

Figure 12. Summary of profiling current meter data collected at stations in the sand-wave fields west of Port Clarence and in Bering Strait during July, 1977. Hachured areas depict major sand ridges with sand wave fields; contour interval is $4 \mathrm{~m}$.

Figure 13. Modification of ice gouges by actively migrating sand waves that is observed in sonographs taken in the area west of Point Spencer, Alaska. Hachured areas depict sand ridge crests with sand waves; contour interval is $4 \mathrm{~m}$. 


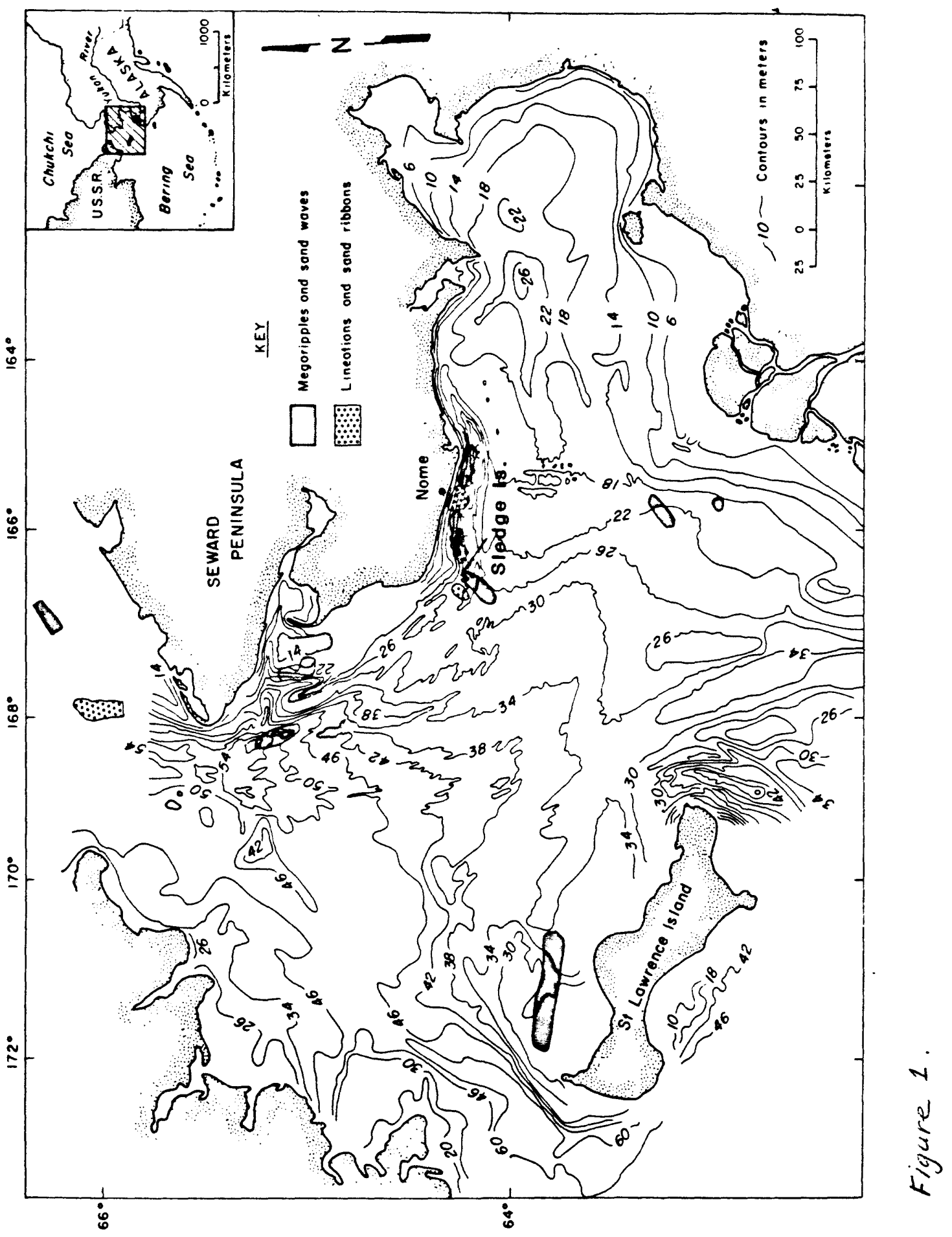




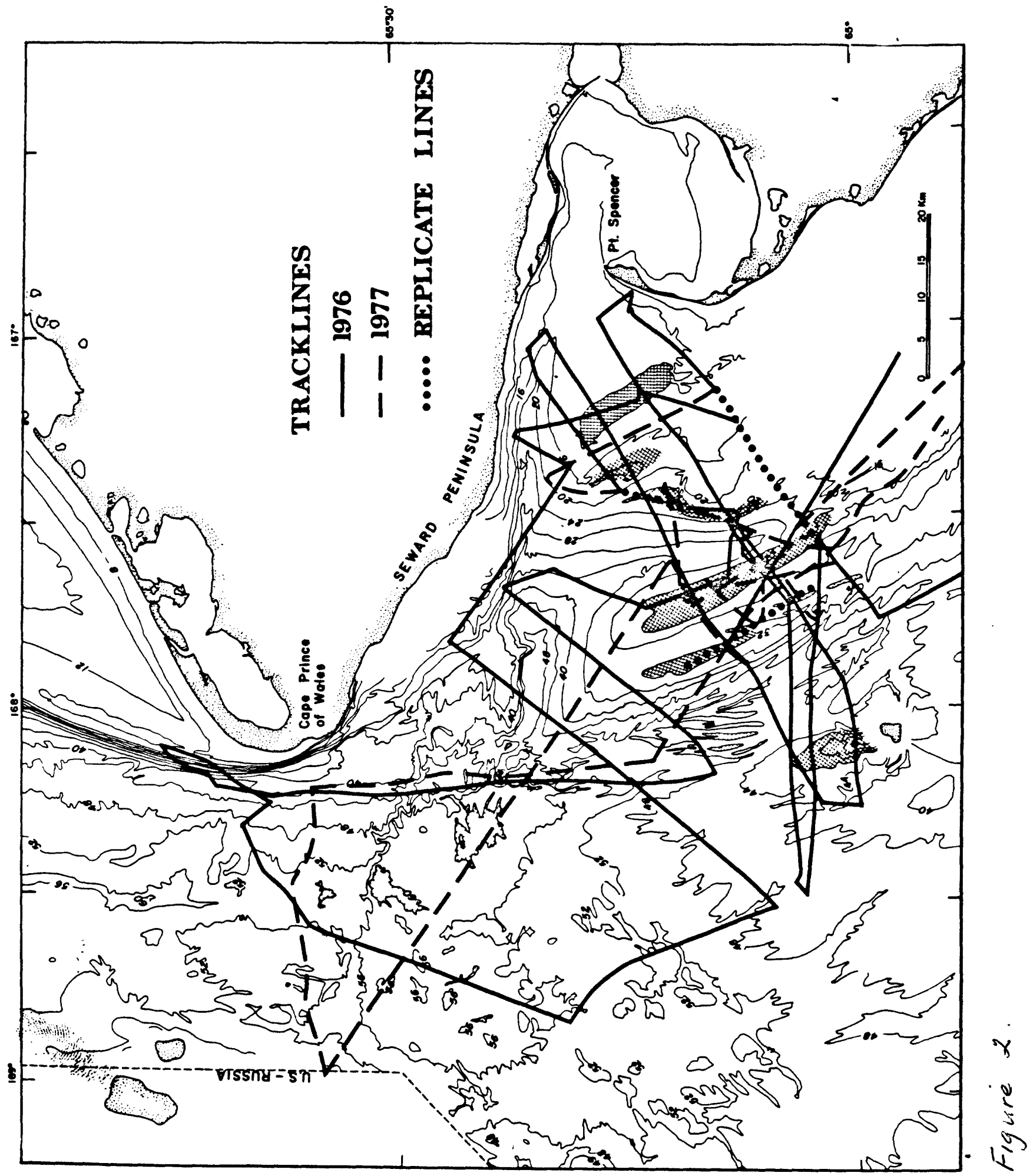




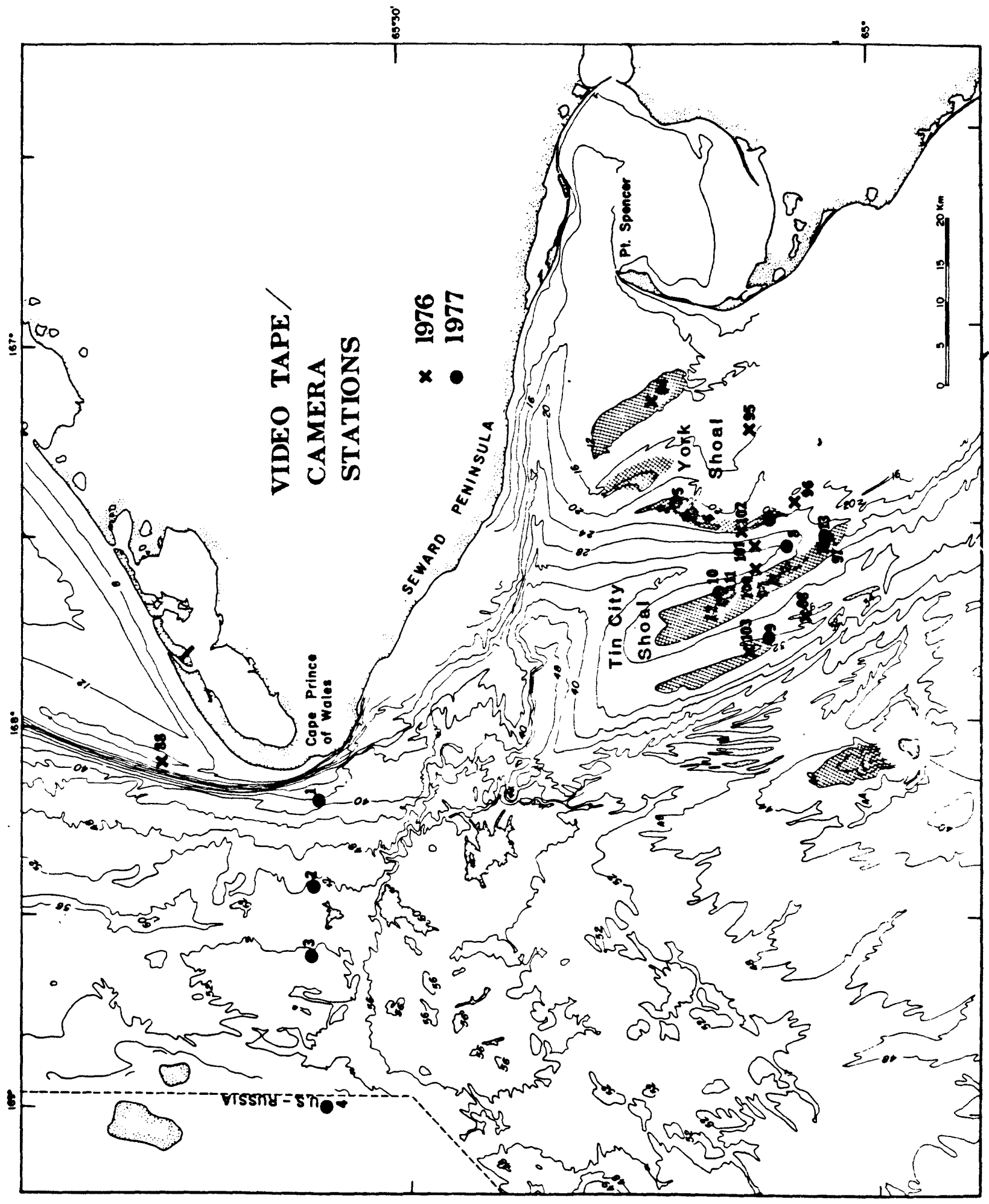

$M$

$\frac{\sqrt{1}}{3}$ 

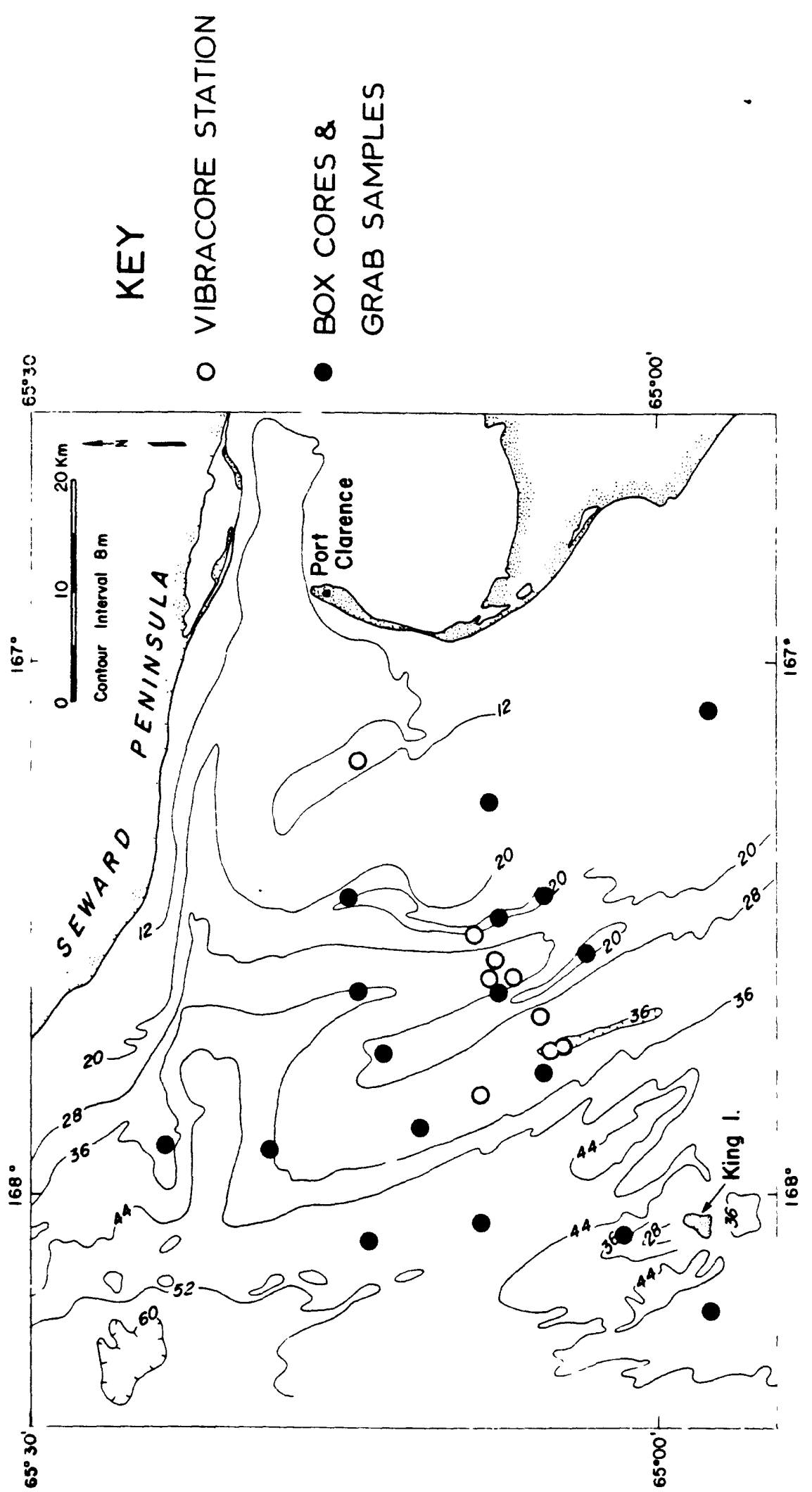

$\frac{1}{3}$ 


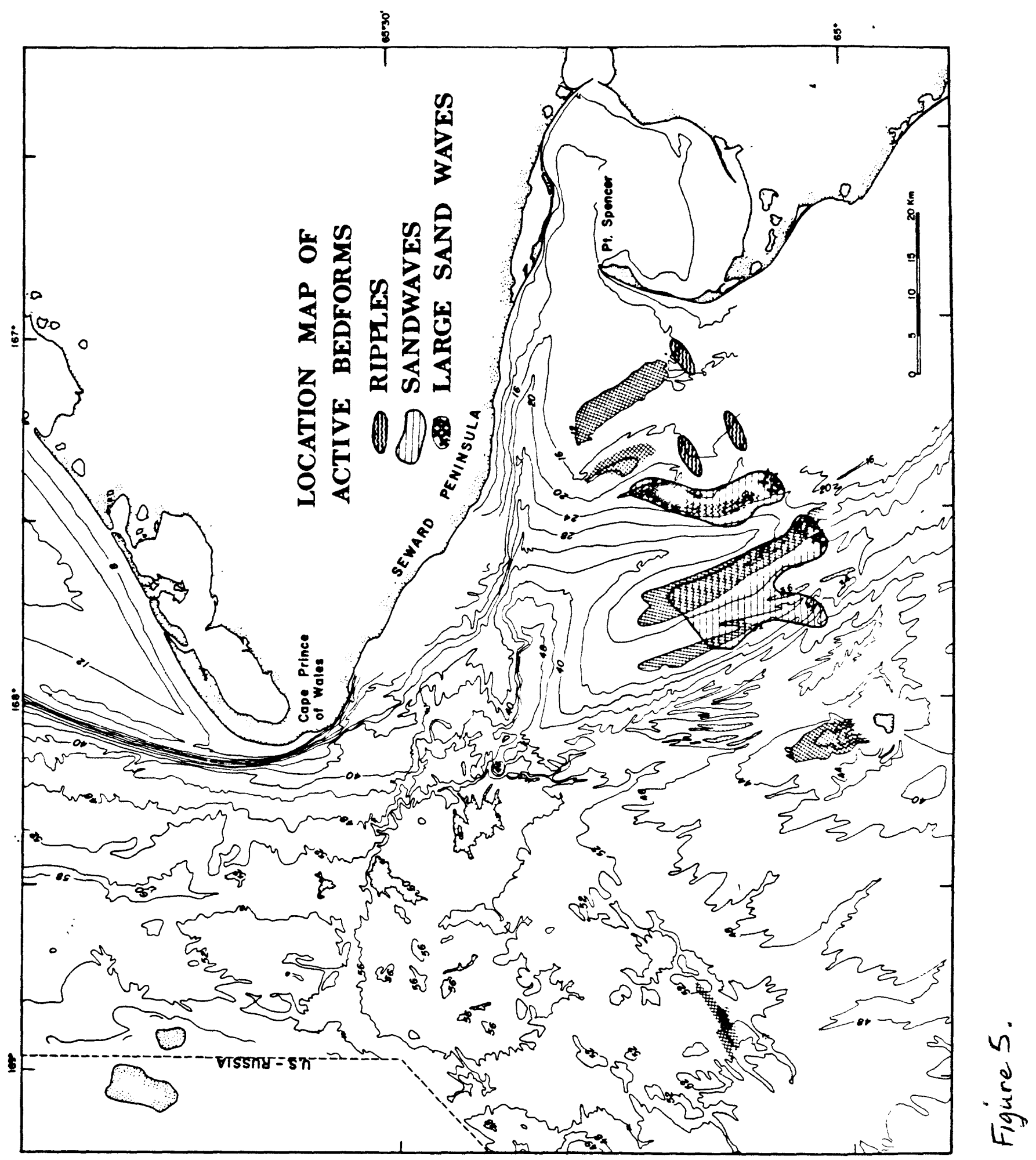




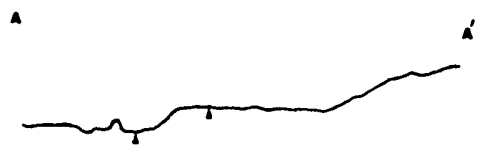

$9 x$

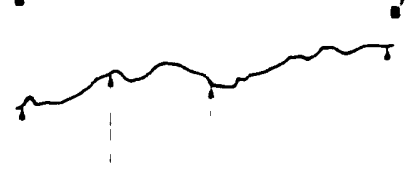

any and ax

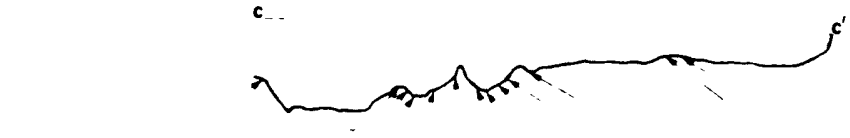

$"[1] \mid+1]$

\section{EXPLANATION}<smiles>CCNC(=O)OCC</smiles>

is BOX CORE

MARINE SEDIMENT

MEDIUM GRAINED

$(0.5 \mathrm{~mm}-0.25 \mathrm{~mm})$

NFINE GRAINED

$(0.25 \mathrm{~mm}-0.031 \mathrm{~mm})$

NON-MARINE SEDIMENT

G MUD AND LIMNETIC PEAT

- 2oK RADIOCARBON DATE

YEARS BP $\times 1000$

- TEXTURAL SAMPLE

IPROFILES: VERT. EXAG. $\times 250$, DATUM IS

MEAM SEA LEVEL

Figure 6. 


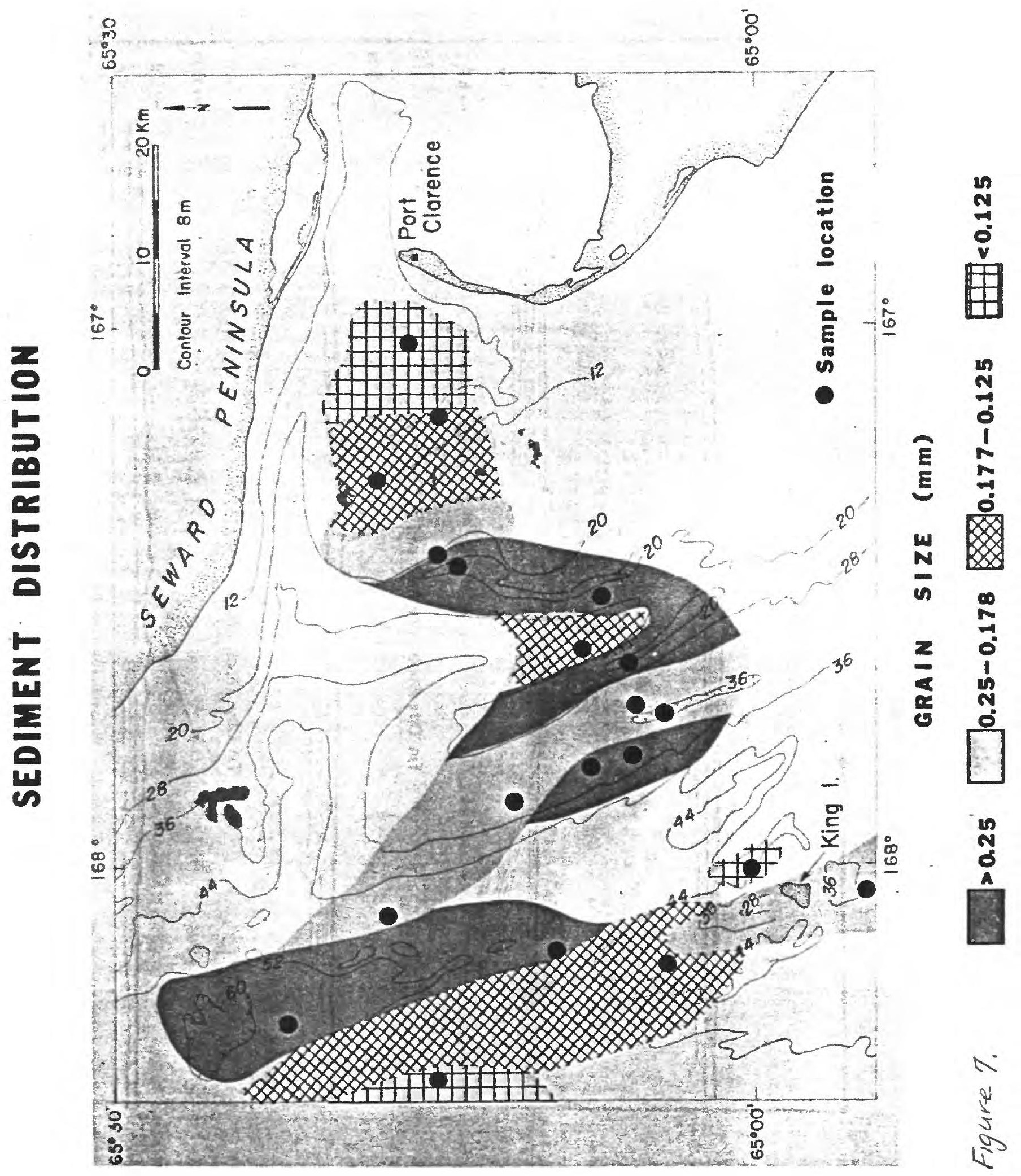




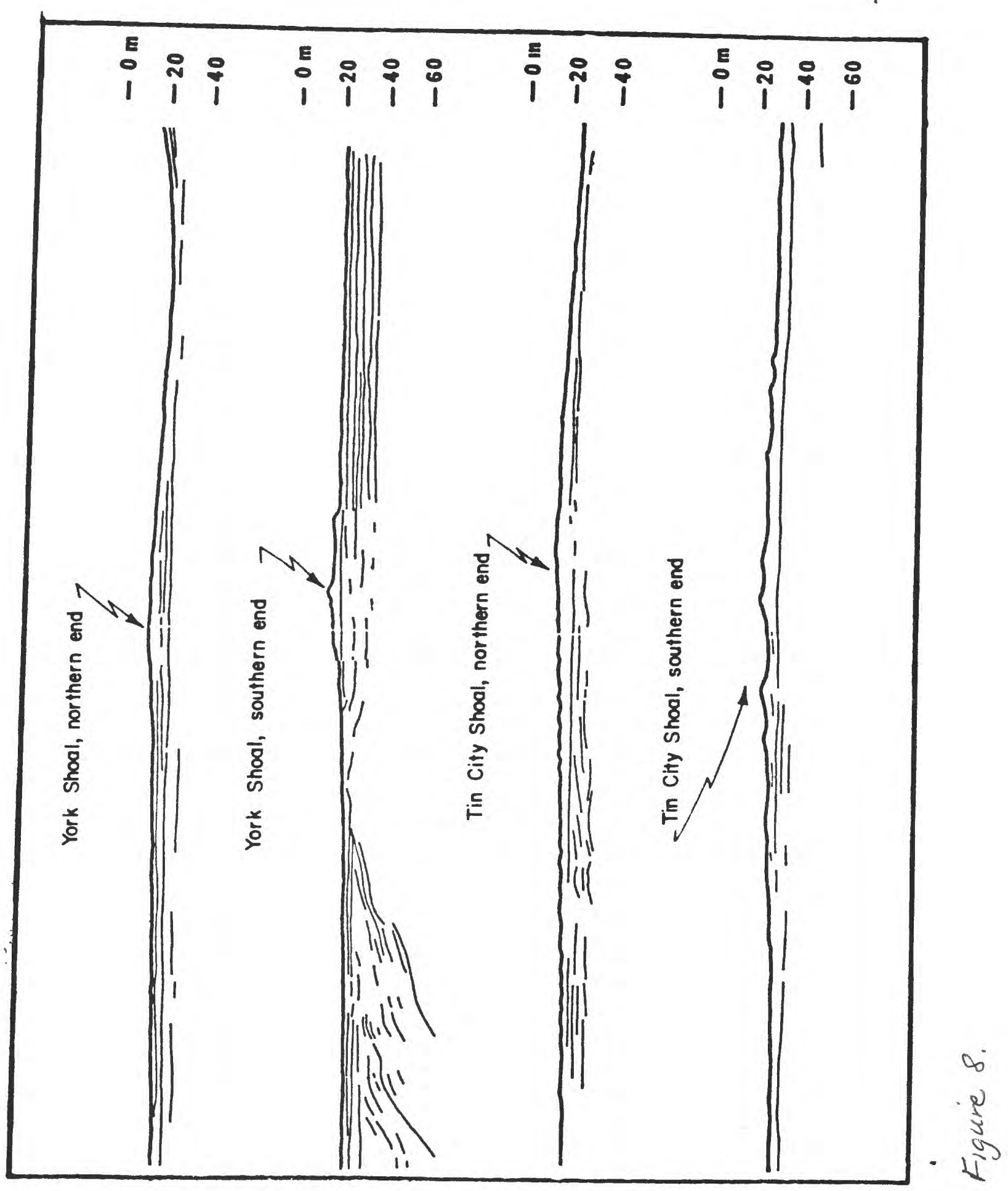



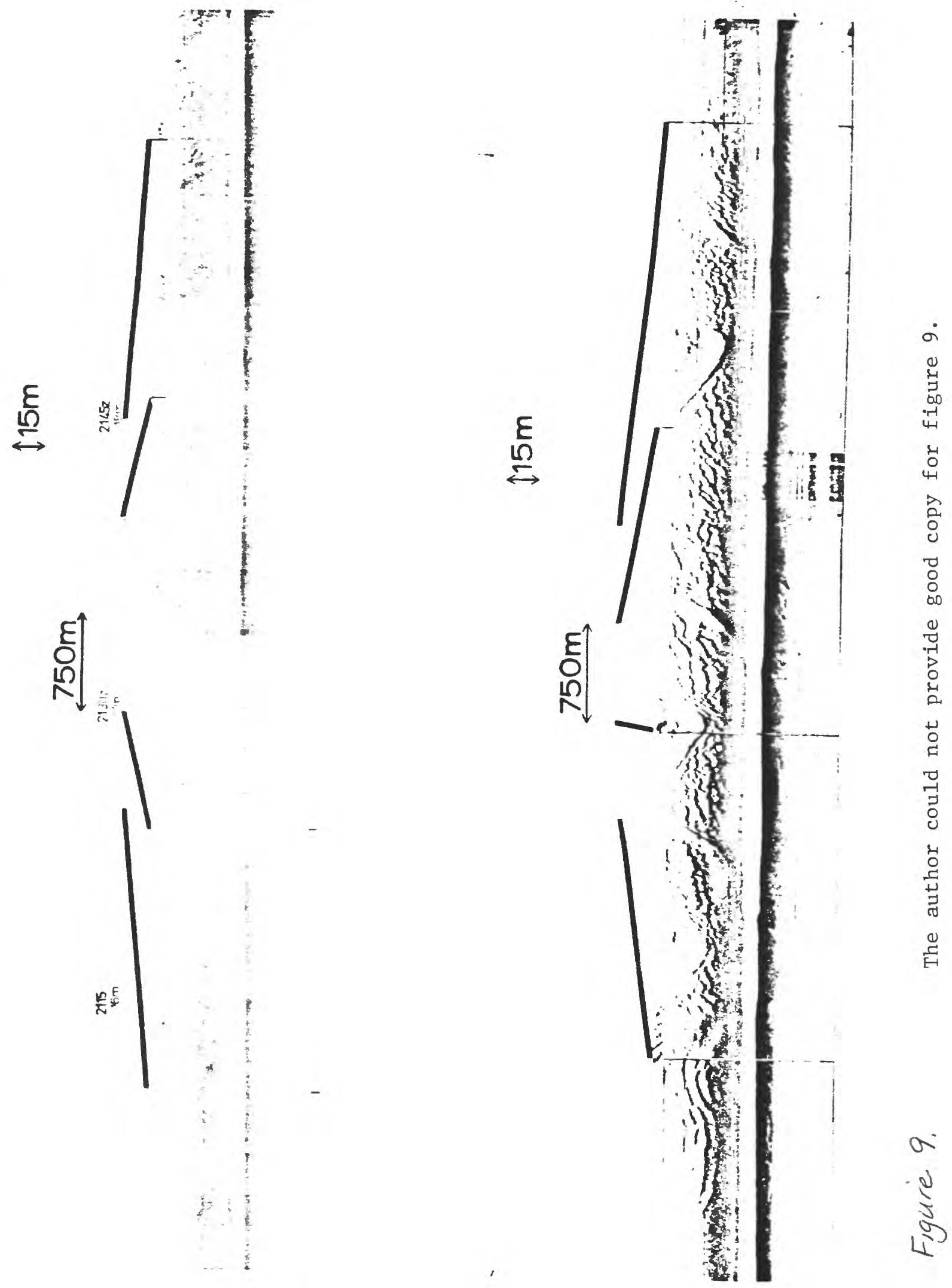

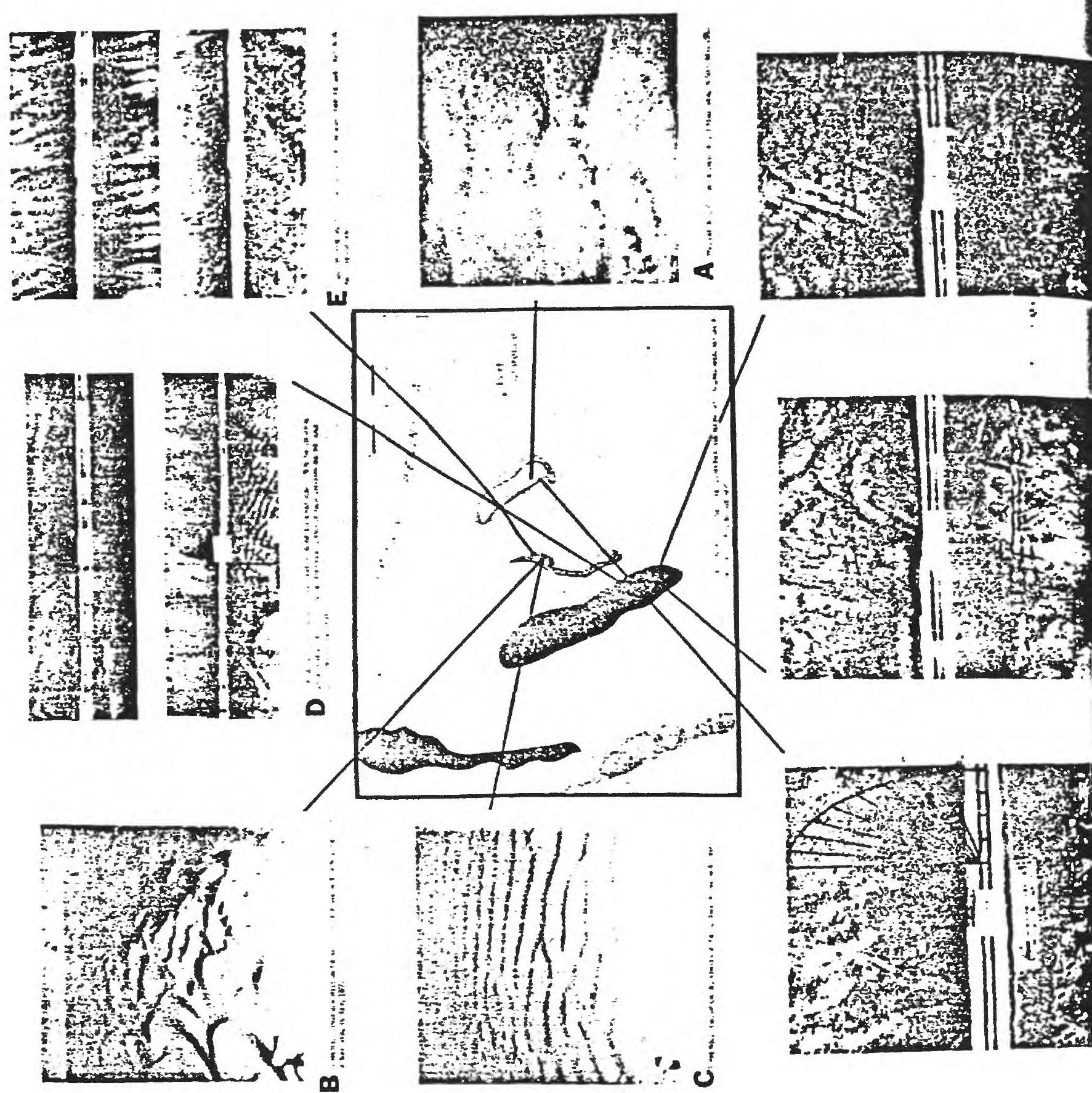

Figure 10. The author could not provide good copy for figure 10.

NOTE :

Figures 9 and 10 have been published in:

"Sand Waves on a Epicontinental Shelf, Northern Bering Sea"

by: Field, M. E., et. al.

Marine Geology, v 42, \#1-4, p 233-258, 1981
Reprints can be obtained from:

C. Hans Nelson

USGS/Marine Geology, MS-99

345 Middlefield Road

Menlo Park, CA 94025 


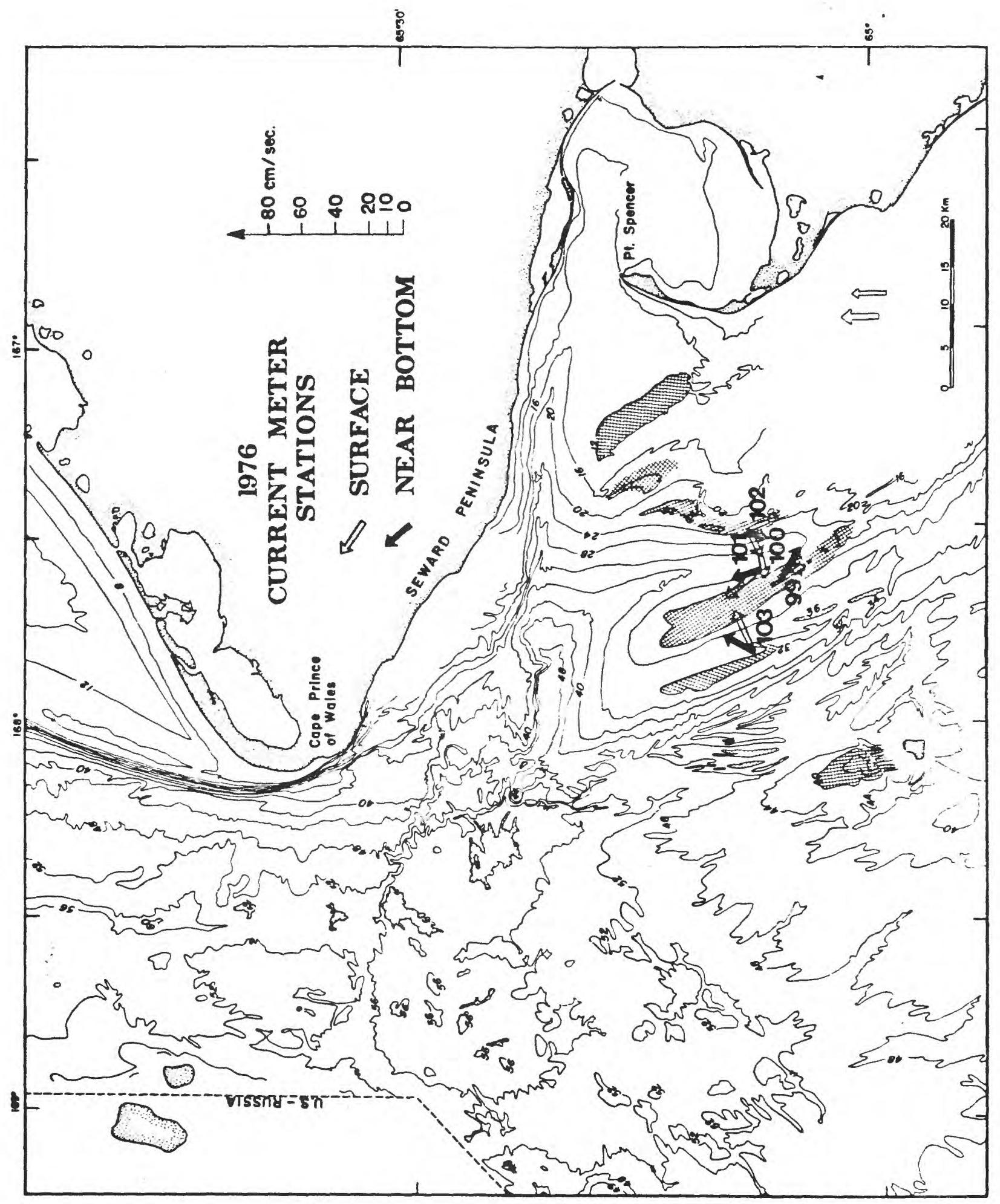

1
2
3
2 


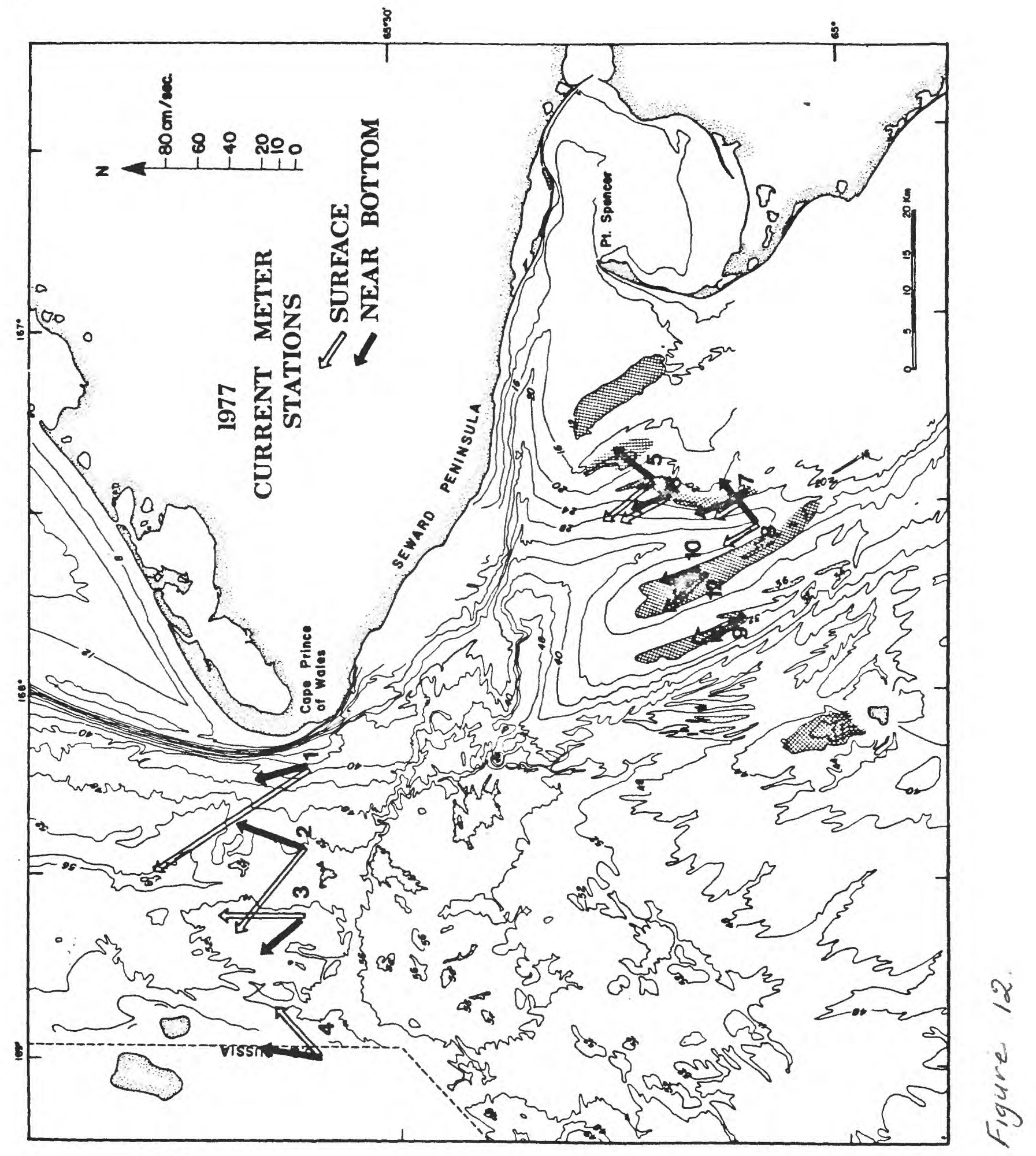




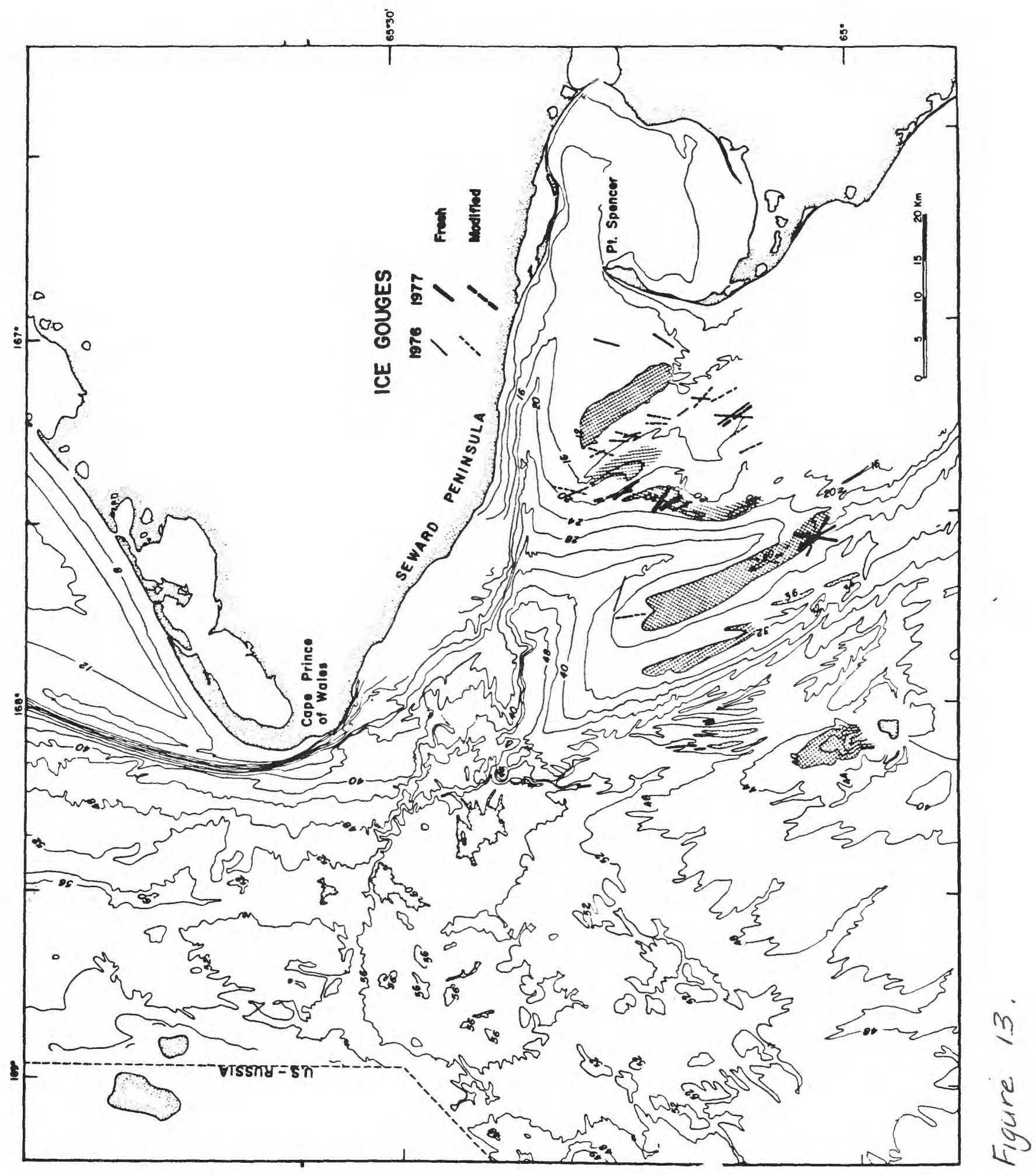

